\title{
Penatalaksanaan Repair Palatoplasty dengan Teknik Furlow Double Opposing Z Plasty
}

\author{
Pingky Krisna Arindra*, Prihartiningsih"**, dan Bambang Dwi Rahardjo** \\ *Program Studi Bedah Mulut dan Maksilofasial, Program Pendidikan Dokter Gigi Spesialis, Fakultas Kedokteran Gigi, Universitas \\ Gadjah Mada, Yogyakarta, Indonesia \\ **Bagian Bedah Mulut dan Maksilofasial, Fakultas Kedokteran Gigi, Universitas Gadjah Mada dan anggota Staf Medik Fungsional \\ RSUP Dr. Sardjito, Yogyakarta, Indonesia \\ *JI Denta No 1 Sekip Utara, Yogyakarta, Indonesia; e-mail: krisnarindra@ugm.ac.id
}

\begin{abstract}
ABSTRAK
Kasus bibir dan lelangit sumbing merupakan salah satu kelainan deformitas yang sering terjadi. Keadaan klinis bervariasi mulai dari kasus sumbing tidak komplit sampai dengan komplit. Keadaan klinis dengan lebar celah yang bervariasi membutuhkan teknik pembedahan yang tepat. Pasien-pasien dengan bibir dan atau lelangit sumbing mungkin sebelumnya telah menjalani beberapa intervensi pembedahan, sehingga sering memerlukan koreksi lebih lanjut untuk memperbaiki hasil operasi sebelumnya. Pasien anak laki-laki usia 4 tahun 7 bulan mengeluhkan masih terdapatnya celah di lelangit. Pasien didiagnosis dengan labiognatopalatoschisis bilateral. Sebelumnya pasein sudah menjalani 4 kali operasi penutupan celah bibir dan lelangit. Pasien menjalani 2 kali operasi bibir sumbing dengan metode lip adhesion dan metode Barsky, dan 2 kali operasi lelangit sumbing dengan metode pushback dilanjutkan dengan koreksi dengan z plasty, tetapi hasil akhir masih terdapat celah di palatum mole. Selanjutnya dilakukan operasi repair palatoplasi dengan metode Furlow double opposing z plasty dengan kombinasi insisi lateral, dan didapatkan hasil menutupnya celah di palatum mole sampai dengan uvula. Telah dilakukan operasi repair palatoplasi dengan metode Furlow double opposing z plasty. Teknik ini dilakukan untuk menghindari insisi yang terlalu luas dikarenakan terdapatnya jaringan fibrous yang tebal pada mukosa palatum pasca operasi sebelumnya. Tujuan studi kasus adalah untuk mengetahui kemampuan teknik Furlow Double Opposing Z Plasty sebagai prosedur repair palatoplasty.
\end{abstract}

Maj Ked Gi Ind. Juni 2015; 1(1): hal 115-121

Kata kunci: repair palatoplasty, double oppazing z plasty

\begin{abstract}
Repair Palatoplasty Management with Furlow Double Opposing Z Plasty Technique. Cases of cleft lip and palate are one of the deformity disorders that often occur. There are variety of clinical appearance ranging from incomplete to complete cases. Clinical appearance with different width requires proper surgical technique. Patients with cleft lip and palate had undergone surgical intervention, so that they needed surgical correction to repair the result or failure of the previous surgery. A Four year old boy complain there was cleft on the soft palate. The patient was diagnosed with labiognatopalatoscisis. The patient had undergone two stages of cleft lip surgery and twice of cleft palate surgery with pushback method and repair with z plasty, however the result was unsatisfactory. Further, the patient underwent repair palatoplasty surgery with Furlow double opposing z plasty method combined with lateral relaxing insicion. The result in the post surgery was the closure of cleft soft palate up to uvula. Repair palataplasty surgery has been done with Furlow double opposing z plasty method. This technique could avoid extended incision due to thick fibrous tissue on the palatum mucosa as the result of serial previous surgery. The aim of this case case study is to determine the technical capabilities of Furlow Double Opposing Z Plasty as palatoplasty repair procedure.

Maj Ked Gi Ind. Juni 2015; 1(1): hal 115-121
\end{abstract}

Keywords: repair palatoplasty, double opposing z plasty

\section{PENDAHULUAN}

Celah pada bibir dan lelangit adalah suatu kelainan bawaan yang terjadi pada bibir bagian atas serta lelangit lunak dan lelangit keras rongga mulut. Celah pada lelangit atau palatoschisis merupakan kelainan kongenital pada atap/lelangit dari mulut yaitu palatum tidak berkembang secara normal selama masa kehamilan, mengakibatkan terbukanya (cleft) palatum yang tidak menyatu sampai ke daerah cavitas nasalis, sehingga terdapat hubungan antara rongga hidung dan mulut. Bibir dan lelangit sumbing merupakan salah satu kelainan deformitas kongenital yang sering terjadi. Keadaan klinis bervariasi mulai bibir sumbing tidak komplit sampai dengan komplit, juga melibatkan prosesus alveolaris maksila, palatum dengan tulang nasal yang terlihat di antara celah. ${ }^{1}$ 
Frekuensi kejadian sumbing yang cukup besar dan ukuran celah yang bervariasi merupakan tantangan bagi ahli bedah mulut untuk melakukan koreksi. Keadaan klinis dengan lebar yang bervariasi membutuhkan teknik pembedahan yang tepat. Selain itu deformitas dengan asimetri yang cukup berat merupakan kesulitan tersendiri dalam koreksi dengan pembedahan. Pasien-pasien dengan bibir dan lelangit sumbing mungkin sebelumnya telah menjalani beberapa intervensi pembedahan, sehingga sering memerlukan koreksi lebih lanjut untuk memperbaiki hasil operasi sebelumnya. 1,3,4

Menurut Berkowitz ${ }^{6}$ bahwa tidak ada metode satupun yang lebih baik jika dibandingkan dengan metode lainnya. Setiap metode terdapat kelebihan dan kekurangannya yang dapat menjadi pertimbangan pada pemilihan teknik pembedahan pada koreksi bibir dan lelangit sumbing. Ada beberapa metode yang dapat digunakan untuk mengkoreksi bibir dan lelangit sumbing. Khusus untuk lelangit sumbing beberapa metode pembedahan yaitu Von Langenback, Pushback Two or Four Flap, dan Furlow. ${ }^{3}$

Bibir dan lelangit sumbing merupakan suatu kelainan kelahiran yang terjadi di daerah mulut dan bibir. Kelainan ini dapat menyebabkan berbagai variasi masalah yang berhubungan dengan rongga mulut, bicara, pendengaran dan mungkin juga mempengaruhi jumlah, ukuran, bentuk dan posisi gigi sulung maupun gigi tetap. Pada kelainan ini membutuhkan evaluasi dini dari team dokter gigi khususnya ahli bedah mulut dan maksilofasial yang biasa menangani bibir dan lelangit sumbing. ${ }^{4}$

Epidemiologi dari bibir dan lelangit sumbing terjadi dua kali lebih banyak pada anak laki-laki, sedangkan lelangit sumbing dua kali lebih banyak terjadi pada wanita. Bibir sumbing dengan atau tanpa celah pada lelangit pada umumnya banyak terjadi pada ras asli amerika, oriental, caucasians dan sedikit terjadi pada ras afrika, sebaliknya celah lelangit terjadi konstan pada semua ras. Kombinasi terjadinya celah pada bibir dan lelangit adalah $30 \%$, celah terisolasi $20 \%$ dan celah bibir dan alveolus $5 \% .{ }^{1,2}$

Etiologi celah lelangit bersifat multifaktorial karena pembentukan celah pada palatum berhubungan dengan faktor herediter dan faktor lingkungan, keduanya terlibat dalam pertumbuhan dan perkembangan processus. ${ }^{2}$ Etiologi dari factor herediter didapatkan data sekitar $25 \%$ pasien yang menderita celah lelangit memiliki riwayat keluarga yang menderita penyakit yang sama. Orang tua dengan celah lelangit mempunyai resiko lebih tinggi untuk memiliki anak dengan celah lelangit. Jika hanya salah satu orang tua yang menderita celah lelangit, maka kemungkinan anaknya menderita celah lelangit adalah sekitar $4 \%$. Jika kedua orangtuanya tidak menderita celah lelangit, tetapi memiliki anak tunggal dengan celah lelangit maka resiko generasi berikutnya menderita penyakit yang sama juga sekitar $4 \%$. Dugaan mengenai hal ini ditunjang kenyataan, telah berhasil diisolasi suatu X-linked gen, yaitu Xq13-21 pada lokus 6p24.3 pada pasien celah bibir dan lelangit. Kenyataan lain yang menunjang, bahwa demikian banyak kelainan/sindrom disertai celah bibir dan lelangit (khususnya jenis bilateral), melibatkan anomali skeletal, maupun defek lahir lainnya. ${ }^{2}$

Untuk celah bibir dengan atau tanpa celah lelangit faktor terjadinya adalah $2 \%$ dengan satu orang tua terpengaruh, $4 \%$ dengan hanya satu saudara sekandung, $9 \%$ dengan 2 saudara sekandung dan $10-17 \%$ dengan satu orang tua dan satu saudara sekandung. Celah lelangit, $7 \%$ dengan satu orang tua terpengaruh, $2 \%$ dengan satu saudara sekandung, $1 \%$ dengan dua saudara sekandung. ${ }^{2}$ Terjadinya celah juga diakibatkan oleh sindrom. Sindrom yang umumnya dapat dihubungkan dengan terjadinya celah lelangit adalah sindrom Apert's, Stickler's dan Treacher Collins, sedangkan sindrom Van der Woudes dan Waardenberg berhubungan dengan terjadinya celah bibir dengan atau tanpa celah lelangit. Faktor lingkungan juga ditemukan sebagai penyebab terjadinya celah seperti ethanol, rubella virus, thalidomide dan aminopterin. Diabetes mellitus maternal dan sindrom amniotic juga sebagai salah satu penyebab terjadinya celah. ${ }^{2,3}$

Faktor lingkungan juga memberikan kontribusi terhadap terjadinya celah lelangit. Obat-obatan yang dikonsumsi selama kehamilan, seperti fenitoin, retinoid (golongan vitamin A), dan steroid beresiko menimbulkan palatoschisis pada bayi. Infeksi selama kehamilan semester pertama seperti infeksi rubella dan cytomegalovirus, dihubungkan 
dengan terbentuknya celah. Alkohol, keadaan yang menyebabkan hipoksia, merokok, dan defisiensi makanan (seperti defisiensi asam folat) dapat menyebabkan palatoschisis. ${ }^{2}$

Kepala dan leher dibentuk oleh beberapa tonjolan dan lengkungan, antara lain processus frontonasalis, processus nasalis medialis dan lateralis, processus maxillaries, dan processus mandibularis. Kegagalan penyatuan processus maxilla dan processus nasalis medial akan menimbulkan celah pada bibir (labioschisis) yang terjadi unilateral atau bilateral. Bila processus nasalis medialis, bagian yang membentuk dua segmen antara maxilla, gagal menyatu maka terjadi celah pada atap mulut atau lelangit yang disebut palatoschisis. ${ }^{2}$

Celah lelangit mempunyai banyak sekali implikasi fungsional dan estetika bagi pasien dalam interaksi sosial mereka terutama kemampuan mereka untuk berkomunikasi secara efektif dan penampilan wajah mereka. Koreksi sebaiknya sebelum anak mulai bicara untuk mencegah terganggunya perkembangan bicara. Penyuluhan bagi ibu si anak sangat penting, terutama tentang cara memberikan minum agar gizi anak memadai saat anak akan menjalani bedah rekonstruksi. Kelainan bawaan ini sebaiknya ditangani oleh tim ahli yang antara lain terdiri atas ahli bedah mulut, dokter spesialis anak, ahli ortodonsi yang akan mengikuti perkembangan rahang dengan giginya, dan ahli logopedi yang mengawasi dan membimbing kemampuan bicara. ${ }^{4}$ maksila pada sisi anterior. Smith mengklasifikasikan fistula berdasarkan letak anatominya di palatum. Klasifikasinya terdiri dari tujuh tipe, tipe I yaitu celah pada uvula (bifid uvula), tipe II fistula pada palatum mole, tipe III fistula pada sisi yang menghubungkan antara palatum durum dan mole, tipe IV yaitu fistula di palatum durum, tipe $V$ yaitu fistula pada palatum primer dan sekunder, tipe VI yaitu fistula pada sisi lingual alveolar, tipe VII yaitu tipe labioalveolar. ${ }^{12}$

Furlow Double Opposing Z Plasty. Furlow palatoplasty dilakukan pada kasus palatum lunak dan celah dangkal unilateral. Biasanya dilakukan pada anak usia lebih dari 5 tahun ketika faringoplasty primer juga diindikasikan. Prinsip dasar dari Furlow z palsty adalah transposisi. Otot palatal dielevasi sebagai bagian dari dasar flap posterior pada tiap z plasty. Bagian nasal z plasty dibuat sebagai gambaran cermin dari lapisan rongga mulut. Flap dibuat dengan membentuk sudut 60 derajat. Pada sisi cleft di insisi terlebih dahulu dan didapatkan mucoperiosteal flap. ${ }^{6}$ Insisi lateral terkadang atau bahkan tidak diperlukan. Lateral relaxingincision dibuat untuk mengurangi ketegangan flap ketika flap ditransposisikan.

Keuntungan dari Furlow palatoplasty adalah didapatkannya pemanjangan palatum tanpa menggunakan jaringan dari palatum durum, diseksi yang presisi dari otot dan transfer otot dimungkinkan. Tingkat kejadian fistula dilaporkan lebih rendah dibandingkan dengan prosedur
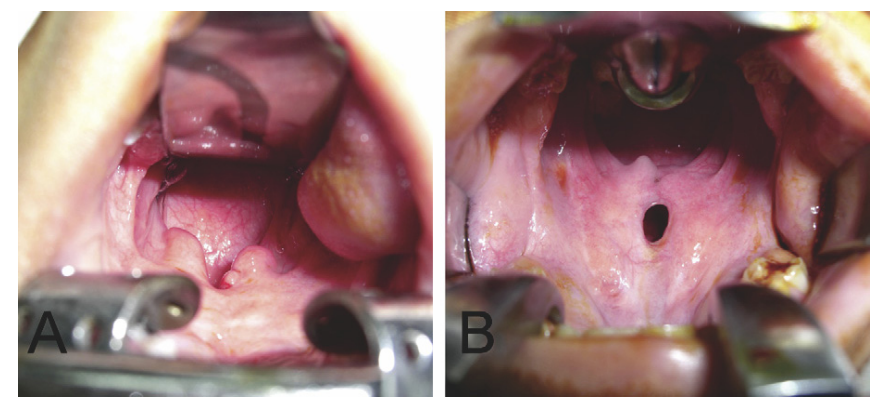

Gambar 1. Fistula pada palatum: (A) contoh tipe I, (B) contoh tipe II

Salah satu komplikasi dari operasi palatoplasty adalah terjadinya fistula. Tingkat kejadiannya berkisar $10-20 \%$. Fistula ini dapat terjadi di sisi manapun, akan tetapi paling umum adalah hubungan antara palatum durum dan palatum mole pada sisi posterior, dan antara premaksila dan lainnya. Velopharyngeal incompetence juga dilaporkan lebih sedikit dibandingkan metode yang lain. Kerugian dari metode ini adalah kesulitan untuk melakukan reopening pada palatum molle dan pembagian otot jika akan dilakukan koreksi operasi sebelumnya. ${ }^{6,7}$ 

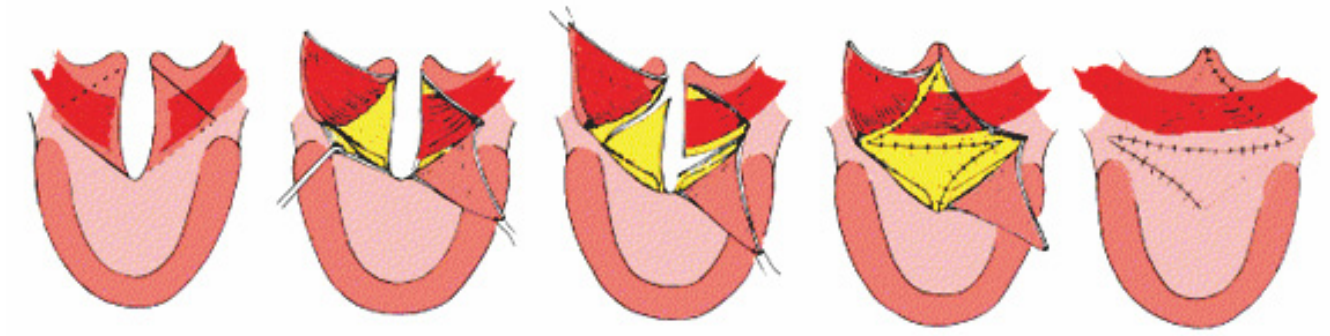

Gambar 2. Desain dan rencana operasi Furlow palatoplasty

Studi kasus ini mengenai penatalaksanaan perawatan perbaikan atau repair pada celah lelangit pada anakusia 4 tahun setelah sebelumnya menjalani operasi untuk mengkoreksi celah bibir dan lelangit sumbingnya. Sebelumnya pasien sudah menjalani 2 kali operasi pentupan celah lelangitnya. Keluarga pasien telah menyetujui perawatan pasien untuk dipublikasikan bagi kepentingan ilmu pengetahuan. Tujuan studi kasus adalah untuk mengetahui kemampuan teknik Furlow Double Opposing Z Plasty sebagai prosedur repair palatoplasty.

\section{METODE}

Pasien anak-anak usia 4 tahun datang ke poliklinik Bedah Mulut RSUP Dr. Sardjito dengan keluhan masih terdapatnya celah di lelangitnya. Riwayat sebelumnya pernah dilakukan operasi penutupan celah bibir dan lelangit sebanyak 4 kali, dan mulai dioperasi mulai umur 4 bulan. Operasi pertama dilakukan pada tahun 2009 untuk mendekatkan celah bibir bilateral dengan teknik lip adhesion. Operasi kedua pada tahun 2010 dilakukan labioplasti bilateral dengan metode Barsky. Operasi selanjutnya adalah penutupan celah lelangit dilakukan pada tahun 2012 dengan teknik two flappushbackpalatoplasy. Hasil dari operasi palatoplasty dengan teknik pushback masih terdapat celah pada palatum mole, selanjutnya dilakukan operasi koreksi dengan z plasty tetapi hasil akhirnya terdapat kegagalan dan masih terdapatnya celah pada palatum molenya.

Pada bulan Januari 2014 dilakukan operasi koreksi celah pada palatum mole dengan teknik Furlow double opposing Z plasty dan direncanakan penambahan lateral relaxing incision untuk mengurangi ketegangan flap. Persiapan operasi dilakukan dengan pemeriksaan penunjang berupa pemeriksaan laboratorium darah, rontgen thorax, dan konsultasi ke bagian anak dan anestesi. Pemeriksaan laboratorium darah menunjukkan $\mathrm{Hb} 11,7 \mathrm{~g} / \mathrm{dl}$, Al $8,6 \times 10^{3} / \mathrm{uL}$, At 301 , PTT 13,1 $\mathrm{s} ;$ APTT 30,2s. Pemeriksaan rontgen thorax menunjukkan pulmo tidak nampak adanya kelainan dan besar jantung normal. Konsultasi ke bagian anak menunjukkan bahwa pasien tidak menderita penyakit sistemik yang akan mengganggu jalannya operasi. Hasil konsultasi dengan sejawat anestesi dihasilkan status fisik ASA I tidak ada kontraindikasi dilakukan operasi. Pasien didiagnosa sebagai postlabiopalatoplasty dengan riwayat labiognatopalatoschisis bilateral komplet. Rencana dilakukan repair di bawah general anestesi dengan teknik Furlowdouble opposing Z plasty.

Operasi dilakukan pada tanggal 16 Januari 2014. Pasien dalam stadium teranestesi dengan oral intubasi, dilakukan tindakan desinfeksi dengan larutan antiseptik pada daerah operasi intra dan ekstra oral. Desain Z-plasty dibuat di area uvulapalatum molle dengan gentian violet. Setelah desain operasi dibuat kemuadian dilakukan injeksi infiltrasi lidokain 1:200.000 di area operasi, Insisi dilakukan sesuai desain operasi dengan pisau no 15 , kemudian dibagi menjadi 2 bagian yaitu bagian mukosa oral dan mukosa nasal yang meliputi otot levator palatini. Setelah mukosa nasal dan mukosa oral terpisah, kemudian pada mukosa nasal dibuat insisi sesuai desain Furlow double opposing z plasty. Ketegangan flap dikurangi dengan membuat lateral relaxing incision di bagian posterior tuber maksilla. Mukosa nasal ditransposisikan sesuai desain, dan dijahit dengan benang vicryl 4.0 teknik interupted simpul dalam. Mukosa oral ditransposisikan sesuai desain, dan dijahit dengan benang vicryl 4.0 teknik interupted. Kontrol perdarahan dan tindakan operasi repaiar palatoplasty selesai dilakukan. 


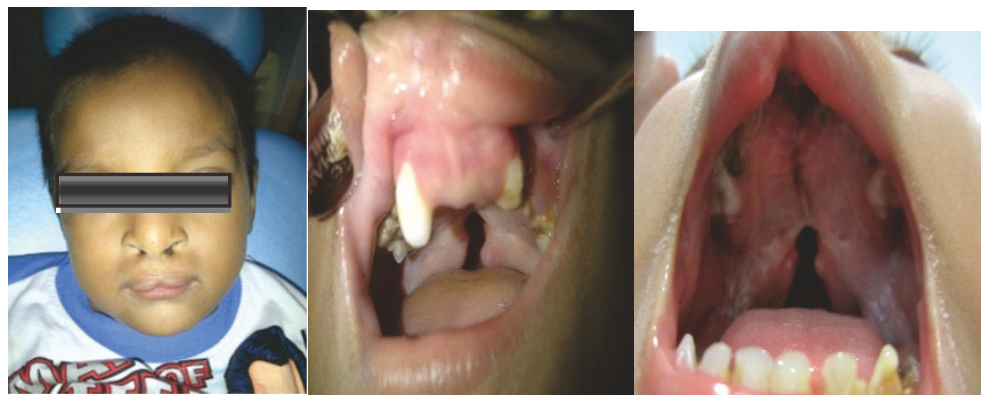

Gambar 3. Foto klinis pasien ekstraoral dan intraoral

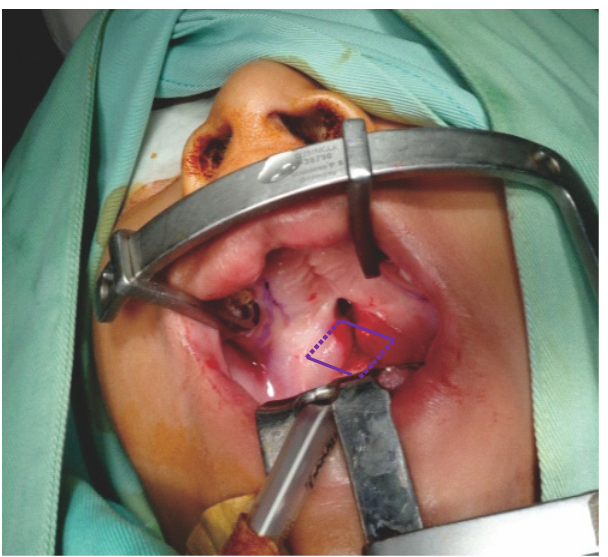

Gambar 4. Desain double z plasty, garis utuh garis insisi mukosa oral garis putus-putus desain insisi mukosa nasal

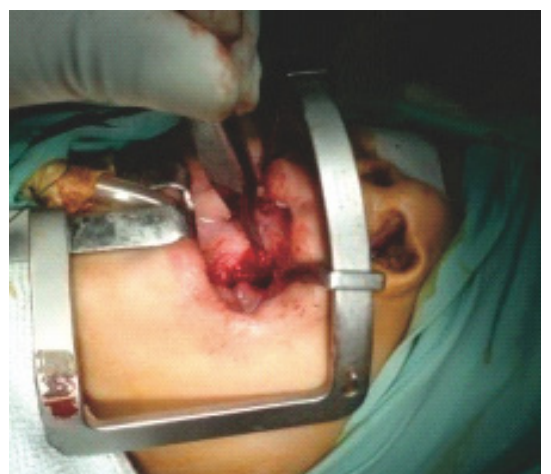

(A)

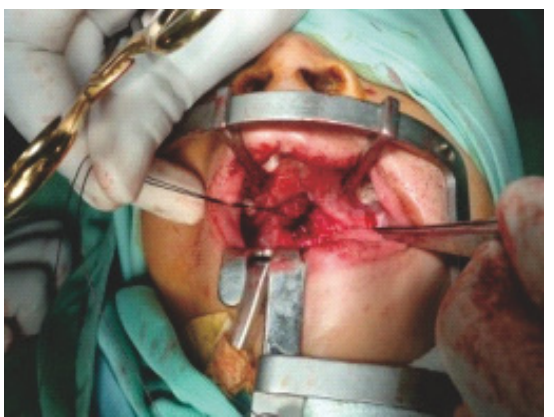

(C)

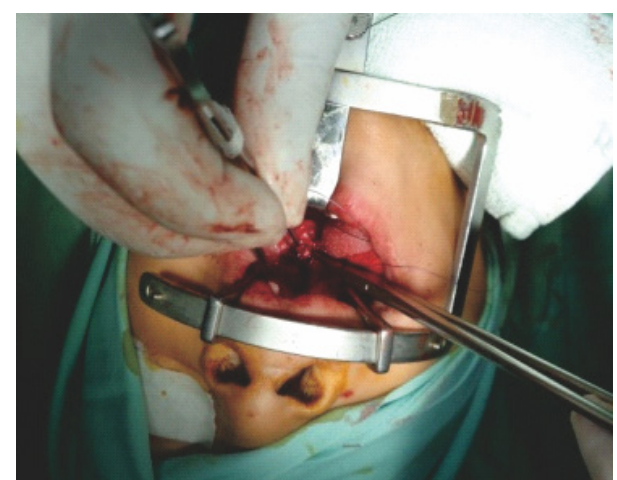

(B)

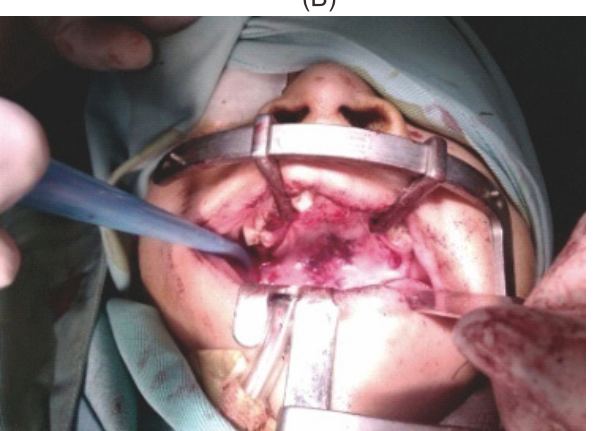

(D)

Gambar 5. Rangkaian operasi: (A) Pemisahan mukosa nasal dan mukosa oral, (B) Proses penjahitan mukosa nasal, (C) Transposisi mukosa oral, (D) Hasil akhir operasi 
Perawatan pasca operasi pasien diberi obatobatan injeksi i.v.Ceftriakson $250 \mathrm{mg}$ tiap 12 jam, injeksi i.v. Novalgin $100 \mathrm{mg}$ tiap 8 jam, injeksi Deksametason 2,5 mg tiap 8 jam, injeksi Asam Traneksamat $125 \mathrm{mg}$ jika perdarahan. Pasien dirawat di bangsal selama 2 hari. Orangtua pasien diinstruksikan untuk memberikan diet/makan hanya cair saja (susu) selama 2 minggu pertama, dan diberi diet cair tinggi kalori tinggi protein. Makan dan minum hanya dengan menggunakan sendok, tidak boleh memakai dot atau sedotan dan menjaga kebersihan rongga mulut. Pasien dipulangkan tanggal 19 Januari 2014 dan diberi obat-obatan yang dibawa pulang Cefadroxil syrup $125 \mathrm{mg}$ tiap 12 jam $1 / 2$ cth, puyer analgetik+roburansia (Paracetamol tablet $125 \mathrm{mg}$, luminal $5 \mathrm{mg}$, vitamin C $35 \mathrm{mg}$, СTM $1 \mathrm{mg}$ ) tiap 8 jam. Pasien kontrol $\mathrm{H}+7, \mathrm{H}+14$ pasca operasi.

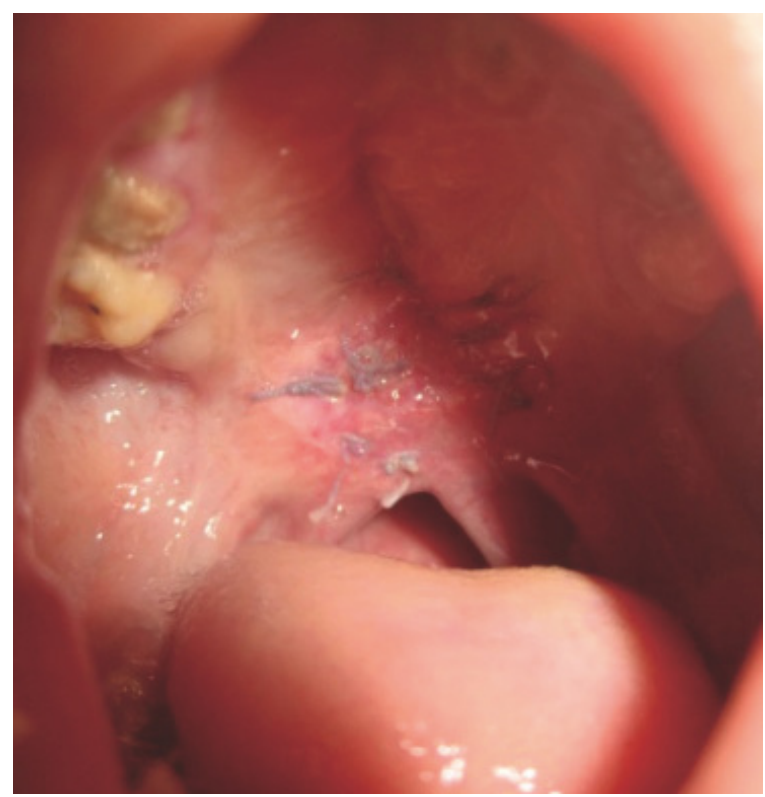

Gambar 6. Kontrol 2 minggu pasca operasi

\section{PEMBAHASAN}

Tidak sempurnanya penutupan celah lelangit pada operasi primer akan menyebabkan terjadinya fistula oronasal pada palatum, sebagai komplikasi dari operasi palatoplasty. Tingkat kejadiannya berkisar $10-20 \%$. Fistula ini dapat terjadi di sisi manapun, akan tetapipaling umumadalah hubungan antara palatum durum dan palatum mole pada sisi posterior, dan antara premaksila dan maksila pada sisi anterior. Fistula dapat menyebabkan regurgitasi dari makanan dan minuman ke kavitas nasal, dan juga ketika udara terlepas selama berbicara dan menghasilkan hipernasal. Fistula dapat terjadi sebagai hasil dari terlalu tegangnya dari luka pada saat akan dilakukan penjahitan, operasi single layer, infeksi dan atau adanya dead space. ${ }^{12}$

Kurang sempurnanya penyatuan palatum mole (soft palate) dari operasi sebelumnya mungkin disebabkan terlalu tegangnya flap pada saat akan dilakukan pernjahitan, operasi single layer, infeksi dan atau adanya dead space, nasal regurgitasi terhadap makanan dan minuman juga bisa karena tekanan suara dari hipernasal. Pada kasus ini kami merawat kegagalan penyatuan palatum mole dengan menggunakan Furlow double opposing z plasty, teknik operasi yang diperkenalkan oleh Leonard Furlow untuk memperbaiki celah lelangit. ${ }^{6}$ Teknik ini dilaporkan meningkatkan Vellopharingeal Clossure (VPC) akibat dari penambahan panjang palatum mole sehingga mendekat ke dinding posterior faring. Teknik ini juga merubah posisi serabut otot levator dari vertikal ke horisontal, sehingga meningkatkan mobilitas palatum. ${ }^{7}$

Perawatan repair palatoplasty dimaksudkan untuk memperbaiki kurang sempurnanya hasil dari operasi sebelumnya, baik itu berupa tidak menyatunya mukosa sehingga menyebabkan terjadinya fistula oronasal. Perawatan ini sulit karena kurangnya jaringan lokal untuk proses penutupan maupun jaringan fibrosis pada area yang sama sebagai hasil dari operasi sebelumnya. ${ }^{7,8,9}$

Pemilihan teknik Furlow double opposing Z-plasty untuk penutupan celah lelangit karena teknik tersebut mampu untuk meningkatkan pergerakan velar dan meningkatkan velopharingeal clossure (VPC) melalui rekonstruksi dari levator sling dan palatal lengthening, sehingga diharapkan pengucapan kata-kata pasien menjadi lebih baik. Hasil fungsional ini dapat mengindikasikan peningkatan mekanisme sphincter dari fungsi velopharingeal valve.9,10 Kekurangan dari teknik Furlow Z-Plasty adalah sulitnya diseksi dan meningkatkan waktu operasi bila dibandingkan dengan teknik operasi palatoplasty lainnya. ${ }^{11}$ Ketegangan flap akibat banyaknya jaringan fibrous, diatasi dengan penambahan lateral relaxing incision, sehingga flap mudah digerakkan dan tidak 
tegang saat penjahitan sehingga meminimalkan terjadinya dehisensi pasca operasi.

Perawatan yang telah dilakukan menunjukkan penutupan komplet dari palatum lunak, tidak menunjukkan adanya dehisensi pasca operasi. Perawatan yang dilakukan bisa memperbaiki hasil operasi sebelumnya. Perawatan repair palatoplasty dengan teknik Furlow dapat digunakan sebagai metode yang efektif dengan tingkat kesuksesan yang baik dan outcome fungsional yang baik.

\section{KESIMPULAN}

Telah dilakukan perawatan repair palatoplasti dengan menggunakan teknik Furlow double opposing $Z$ plasty dengan penambahan lateral relaxing insicion dengan hasil perawatan dan outcome fungsional yang baik. Perawatan celah lelangit yang lebar membutuhkan perhatian khusus terutama bagi dokter ahli bedah mulut karena kemungkinan terjadinya kegagalan penyatuan celah pasca operasi. Hasil dari laporan ini menunjukkan bahwa teknik Furlow double opposing Z-plasty dapat digunakan sebagai alternatif teknik perawatan repair palatoplasty.

\section{DAFTAR PUSTAKA}

1. Shaye D, Liu CC, Tollefson TT. Cleft lip and palate: an evidence-based review. Facial Plast Surg Clin North Am. 2015; 23(3): 357-72.

2. Hathaway RR, Long RE. Early cleft management: in search of evidence. Am J Orthod Dentofacial Orthop. 2014; 145(2): 13541.

3. Throton JB. The Incidence, Classification Ethiology and Embriology of Oral Cleft, Seminorthod, 1996: 162-169.

4. Donald RE, Avery DR. Dentistry for the child and adolescent, Mosby, Toronto. 2000: 742772.
5. Ma QL, Conley RS, Wu T, Li H. Interdisciplinary treatment for an adult with a unilateral cleft lip and palate. Am J Orthod Dentofacial Orthop. 2014; 146(2): 238-48.

6. Berkowitz S. The cleft palate story. Quintes Publishing Co, Chicago. 1997: 141-145.

7. Furlow LT. Cleft palate repair by double opposing z-plasty. Plast Reconstr Surg. 1986: 76, 727-73.

8. Reddy RR, Reddy SG, Banala B, Bronkhorst E, Kummer AW, Kuijpers-Jagtman AM, Bergé SJ. Use of a modified furlow z-plasty as a secondary cleft palate repair procedure to reduce velopharyngeal insufficiency. Int J Oral Maxillofac Surg. 2015; (15)00265-9.

9. Pasick CM, Shay PL, Stransky CA, Solot CB, Cohen MA, Jackson OA,. Long term speech outcomes following late cleft palate repair using the modified furlow technique. Int $\mathrm{J}$ Pediatr Otorhinolaryngol. 2014; 78(12): 227580.

10. Hsu PJ, Wang SH, Yun C, Lo LJ. Redo doubleopposing z-plasty is effective for correction of marginal velopharyngeal insufficiency. J Plast Reconstr Aesthet Surg. 2015; 68(9): 1215-20.

11. Muzaffar AR, Rice G, Hubbard B, Killion E. Influence of preoperative velar closing ratio and lateral wall movement on outcomes of Furlow palatoplasty forvelopharyngeal incompetence. Plast Surg (Oakv). 2014; 22(4): 226-8.

12. Chim H, Eshraghi $Y$, Lamphongsai $S$, Gosain AK. Double-Opposing z-palatoplasty for secondary surgical management of velopharyngeal incompetence in the absence of a primary furlow palatoplasty. Cleft Palate Craniofac J. 2015; 52(5): 517-24.

13. Smith DM, Vecchione L, Jiang $S$. The pittsburgh fistula classification system: a standardized scheme for the description of palatal fistulas, Cleft Palate. Craniofac. J. 2007; 44: 590-594. 